\title{
Transformasi Media Pembelajaran Sebagai Upaya Optimalisasi Perkuliahan Agama Hindu Pada Mata Kuliah Inti Prodi Penerangan Agama Hindu STAH Negeri Mpu Kuturan Singaraja
}

\author{
Gede Agus Jaya Negara', I Nyoman Ariyoga ${ }^{2}$, I Nyoman Buda Asmara Putra ${ }^{3}$ \\ ${ }^{123}$ STAHN Mpu Kuturan Singaraja \\ ${ }^{1}$ gedeagusjayanegara@gmail.com, ${ }^{2}$ nyomanariyoga92@gmail.com, \\ 3inyomanbudaasmaraputra29@gmail.com
}

\begin{abstract}
The Hindu Religious Information Study Program, STAHN Mpu Kuturan Singaraja, is committed to producing Hindu religious instructors who have competencies according to the profile of graduates. The process of supporting the existence of the Hindu Religious Information Study Program requires optimization of core courses, one of which is Hinduism by carrying out a transformation of learning media, especially during the Covid-19 pandemic. The purpose of this study was to identify the transformation of learning media, to know the process of transforming learning media, and to identify the impact of the transformation of learning media to the core courses of Hindu Religious Information Study Program. This type of research is qualitative research, namely research that produces descriptive data in the form of words. Through analysis based on the theory of behaviorism and the theory of social change, Technological Determinism. The results of this study are preparing supporting facilities, participating in training, exchanging information and knowledge, and social media-based assignments. To support these efforts, the learning media transformation process includes: the selection of learning media and the implementation of distance learning media transformation in the Hindu Religious Information Study Program. The implication is that by increasing digital literacy, gaining ease in accessing information, being flexible, efficient and of good quality), the results of the research conclude that students are skilled in using social media as well as increasing the ability of lecturers and students in using IT, increasing student scores, and STAH Negeri Mpu Kuturan Singaraja institutions is ready in terms of digital transformation for mutual progress.
\end{abstract}

Keywords: Transformation of Learning Media; Hinduism; Optimization of Lectures

\section{Abstrak}

Prodi Penerangan Agama Hindu STAHN Mpu Kuturan Singaraja, berkomitmen dalam mencetak SDM Penyuluh Agama Hindu yang memiliki kompetensi sesuai dengan profil lulusan. Proses menopang eksistensi Prodi Penerangan Agama Hindu perlu adanya optimalisasi terhadap mata kuliah inti salah satunya mata kuliah Agama Hindu dengan melakukan sebuah transformasi media pembelajaran terlebih lagi di massa pandemi Covid19. Tujuan penelitian ini adalah untuk mengidentifikasi upaya transformasi media pembelajaran, mengetahui proses transformasi media pembelajaran, dan mengidentifikasi dampak transformasi media pembelajaran terhadap perkuliahan mata kuliah inti keilmuan Prodi Penerangan Agama Hindu. Jenis penelitian ini adalah penelitian kualitatif yaitu penelitian yang menghasilkan data deskriptif berupa kata-kata. Melalui analisis berdasarkan teori behaviorisme dan teori perubahan sosial Technological Determinism. Hasil dari penelitian ini yaitu menyiapkan sarana pendukung, mengikuti pelatihan, bertukar informasi dan ilmu, dan penugasan berbasis media sosial. Menunjang upaya tersebut maka proses transformasi media pembelajaran mencakup: pemilihan media pembelajaran dan pelaksanaan 
transformasi media pembelajaran jarak jauh di Prodi Penerangan Agama Hindu. Implikasinya dengan meningkatkan literasi digital, memperoleh kemudahan dalam mengakses informasi, bersifat fleksibel, hemat dan berkualitas), capaian dari hasil penelitian berupa simpulan yakni mahasiswa terampil menggunakan media sosial serta meningkatnya kemampuan dosen dan mahasiswa dalam penggunaan IT, meningkatnya nilai mahasiswa, dan lembaga STAH Negeri Mpu Kuturan Singaraja siap dalam hal transformasi digital demi kemajuan bersama.

Kata Kunci: Transformasi Media Pembelajaran; Hindu; Optimalisasi Perkuliahan

\section{Pendahuluan}

Manusia hidup di dunia yang senantiasa berubah, kebiasaan dan aturan-aturan kesusilaan, hukumnya, lembaga-lembaga terus berubah. Semua perubahan tersebut mengakibatkan perubahan yang lain terjadi secara timbal balik. Masyarakat dan budayanya terus mengalami perubahan. Mayor Polak (1985:385) menyatakan bahwa transformasi berarti perubahan atau sesuatu yang melampaui. Perubahan sosial senantiasa terjadi seiring dengan perkembangan manusia, dulu masyarakat dikenal dengan kehidupan agraris tetapi sekarang telah berubah menjadi masyarakat industri. Perubahan tersebut wajib untuk dimanfaatkan, agar segala bentuk tujuan tercapai dan hasil pemanfaatan berawal dari sebuah strategi. Strategi yang baik tentu memberikan hasil maupun dampak yang baik pula.

Fungsi strategis pendidikan tinggi adalah untuk menemukan dan menggali kemampuan yang dimiliki manusia untuk disempurnakan kemudian dikembangkan menjadi insan yang berkualitas. Saat ini, pendidikan tinggi tidak hanya berada di ranah menghasilkan lulusan yang cerdas dan siap pakai, tetapi perguruan tinggi harus mampu mencerahkan mahasiswa, memahami hakikat identitas keagamaan dan memainkan peran moral di masyarakat. Hal ini sebagaimana tertuang dalam Pasal 1 UU No. 20 Tahun 2003 tentang Sistem Pendidikan Nasional, dimana pendidikan pada perguruan tinggi merupakan suatu cara yang sistematis dalam mengembangkan kemampuan diri melalui kekuatan spiritual keagamaan dan pendalaman diri, kepribadian dan kecerdasan, moralitas, nilai-nilai luhur, dan keterampilan yang dibutuhkan oleh peserta didik, masyarakat dan negara.

Perkembangan menuju potensi tersebut merupakan tujuan mulia dari pengajaran di lembaga pendidikan tinggi. Tujuan mulia ini tertuang dalam UU No. 12 Tahun 2012, dimana pendidikan tinggi memiliki tujuan untuk meningkatkan kemampuan peserta didik dan menjadi orang yang beriman dan bertakwa kepada Tuhan Yang Maha Esa. Selain itu, peserta didik harus menjadi sehat, cakap, kreatif, mandiri, terampil, dan berakhlak mulia. Jenjang pendidikan taman kanak-kanak (TK) hingga diperguruan tinggi, Pendidikan agama Hindu wajib dilaksanakan di lembaga pendidikan formal, baik swasta maupun negeri. Pendidikan agama Hindu sama seperti mata pelajaran yang lainya bertujuan untuk mewujudkan tujuan nasional. Depdiknas mempersiapkan peserta didik untuk mengenal, memahami, menghayati, beriman, bertakwa dan berkepribadian mulia dalam mengamalkan ajaran Hindu dari sumbernya yaitu Sruti, Smerti, Sila, Acara dan Atmanastuti. Hal ini seiring dengan pengembangan standar kompetensi mata pelajaran agama Hindu dalam kurikulum 2004 yang dapat dipahami sebagai upaya sadar dan sistematis. Pendidikan agama Hindu memberikan ruang untuk menjadi manusia yang selaras, serasi dan seimbang di dalam kehidupan

Di masa pandemic Covid-19, termasuk bidang pendidikan, dampaknya besar. Lembaga formal baik dari jenjang dan TK hingga perguruan tinggi, memerlukan persiapan untuk melakukan transformasi dalam media pembelajaran online. Ragam manfaat dari kemudahan dalam pelaksanaan pelajaran online juga dikarenakan berbagai platform media pembuat aplikasi-aplikasi yang bisa dipakai untuk diskusi sampai tatap muka secara virtual (Herliandry, Nurhasanah, Suban, \& Heru, 2020). Perubahan media pembelajaran dalam pendidikan agama Hindu antara lain kombinasi teknologi Cyber dan otomasi. Oleh karena 
itu, perguruan tinggi fokus memenuhi kebutuhan yang didukung oleh Internet of Things, big data, dan cybersecurity.

Penjelasan singkat yang ditangkap dalam pembahasan tentang perkembangan Revolusi Industri 4.0 adalah kemajuan teknologi informasi berbasis internet berkecepatan ultra tinggi yang dapat digunakan untuk mendukung penyelenggaraan pendidikan Perguruan Tinggi (Karim, 2020). Pengembangan Perguruan Tinggi juga tidak terlepas dari pengembangan Program Studi yang ada. Pengembangan Program Studi Penerangan agama Hindu yang ada di STAHN Mpu Kuturan Singaraja sangatlah penting untuk mencetak SDM Penyuluh Agama Hindu yang memiliki kompetensi sesuai dengan profil lulusan Penerangan Agama Hindu. Untuk mendukung proses perkuliahan, sarana dan prasarana yang cukup memadai dapat mempermudah mahasiswa maupun dosen dalam proses pembelajaran yang dapat dimanfaatkan guna menunjang kegiatan Tri Dharma Perguruan Tinggi. Untuk menopang eksistensi program studi Penerangan Agama Hindu perlu adanya optimalisasi terhadap mata kuliah inti keilmuan pada Prodi Penerangan Agama Hindu. Lebih lanjut Prodi Penerangan Agama Hindu mempunyai mata kuliah inti keilmuan yang menopang profil lulusan, sehingga setelah lulus mahasiswa bisa siap dalam dunia kerja sebagai penyuluh maupun dalam hal memberikan tranformasi ajaran-ajaran Agama Hindu.

Mata kuliah yang dipilih sebagai mata kuliah inti keilmuan didasarkan pada kompetensi yang harus dimiliki oleh lulusan Prodi Penerangan Agama Hindu. Oleh sebab itu optimalisasi perkuliahan khususnya mata kuliah inti keilmuan di Prodi Penerangan Agama Hindu perlu adanya sebuah transformasi dalam kondisi pandemi covid-19, terutama pada media pembelajaran yang dipakai oleh para dosen dalam proses pembelajaran. Transformasi ini harus dilakukan oleh Program Studi Penerangan Agama Hindu dengan tujuan untuk menciptakan lulusan yang unggul baik dari segi soft skills maupun hard skills, sehingga mampu mempersiapkan diri dan beradaptasi dengan perkembangan zaman dan menyiapkan kebutuhan lulusan yang mampu menjadi pemimpin masa depan bangsa dengan berbekal kepribadian yang baik dan unggul. Program experiential learning dengan jalur yang fleksibel diharapkan mampu mengembangkan potensi mahasiswa sesuai dengan passion dan bakatnya.

Berdasarkan perihal tersebut untuk membentuk karakter penyuluh agama Hindu yang berkualitas dan cakap dalam bidang intelektual, emosional, dan spiritual dari Prodi Penerangan Agama Hindu, diperlukan optimalisasi mata kuliah Agama Hindu. Terdapat 3 hal hal yang dianalisis terkait upaya-upaya yang dilakukan dalam mentransformasi media pembelajaran, proses transformasi media pembelajaran yang dilaksanakan untuk mengoptimalisasikan perkuliahan mata kuliah inti (Agama Hindu) pada Program Studi Penerangan Agama Hindu, dan implikasi dari transformasi media pembelajaran mata kuliah inti keilmuan pada Program Studi Penerangan Agama Hindu.

\section{Metode}

Penelitian yang diguakan adalah jenis penelitian kualitatif, penelitian kualitatif tidak menekankan pada kuantum atau jumlah, melainkan menghasilkan data deskriptif berupa katakata. Dalam penelitian ini mengunakan analisis interpretatif dengan pendekatan teori behaviorisme dalam trasformasi media pembelajaran di Prodi Penerangan Agama Hindu. Selain itu penelitian mengunakan pendekatan teori perubahan sosial, dalam menjelaskan fenomena perubahan sosial, August Comte (Suryono, 2019) melihatnya sebagai suatu proses evolusi atau "evolusi intelektual" yang terjadi dalam proses perubahan bertahap dari daya pikir masyarakat itu sendiri. Perkembangan intelektual yang disebutkan dalam penelitian ini terkait dengan penggunaan media pembelajaran online. Data primer penelitian ini yaitu mata kuliah inti di Prodi Penerangan Agama Hindu yang dianalisis sesuai dengan capaian dari kurikulum KKNI yang diterapkan di Prodi Penerangan Agama Hindu. Sumber data sekunder didapatkan dari artikel-artikel serta referensi buku yang mendukung penelitian. 
Dalam memperoleh data yang sahih pada penelitian ini menggunakan metode pengumpulan data berupa studi kepustakaan, observasi, dan wawancara terstruktur secara terarah untuk mengidentifikasi informan. Analisis data dilakukan dengan berpedoman pada Miles dan Huberman (Diantara, 2011). menyatakan bahwa pada dasarnya analisis data pada pandangan paradigmanya yang positifisme. Miles dan Huberman menyatakan bahwa pengolahan data kualitatif melibatkan tiga langkah yakni reduksi data (data reduction), penyajian data (data display), serta penarikan kesimpulan (conclusion drawing and verification)

\section{Hasil dan Pembahasan}

Pendidikan Agama Hindu memegang peranan penting dalam Negara Kesatuan Republik Indonesia. Agama dapat meningkatkan Sradha umatnya dan dapat juga meningkatkan perilaku yang luhur, sopan, santun, meningkatkan kesejahteraan dalam menjalankan tugas atau kewajiban baik dirinya pribadi maupun kepentingan masyarakat serta mencerdaskan kehidupan berbangsa dan bernegara berdasarkan konsep keagamaan. Tujuan ini sejalan dengan apa yang telah tertuang dalam sarasmuscaya 402, sebagai berikut;

lka tang punggung, yatika klabakenanta, makasādhanang kaprajùāna, prajñā ngaraning tutur tan pahingan, si wruh ta ring wastu tattwa, apan sang paõóita, wênang sira mengêntasakên wwang len tuwi, sangkeng bhawārõawa, makasādhanang parahu, winangun dening kaprajñāanira, kunang ikang apunggung, tan hanang kaprajùāna iriya, awaknya tuwi, tan kāntas denya

Terjemahannya :

Kebodohan itulah yang harus anda lenyapkan dengan kaprajnan; prajna adalah kesadaran yang tiada hingganya; pengetahuan tentang hakekat barang sesuatu; karena sang pandita, sanggup menyeberangkan orang lain dari samudra kelahiran dengan perahu yang diperbuat daripada keprajnananira (pengetahuan beliau); akan letapi si bodoh tidak ada kaprajnan (kecerdasan akal budi) padanya; dirinya sendiri tidak terseberangkan olehnya

Penting bagi setiap individu khususnya yang belajar pendidikan agama Hindu agar terbebas dari kebodohan, baik secara jasmani maupun rohani, karena tanpa pengetahuan yang didapatkan dalam jenjang pendidikan, terlebih pendidikan Agama Hindu maka hanya kegelapan yang akan muncul.

Kunang ikang apunggung, niyata juga ya humidêp ikang kaprihati, makahetu patêmunya lawan keliknya, papasahnya lawan kāsihnya, arah denyāhangkāranya, makanimitta punggungnya (Sarasmucaya, 404)

Terjemahannya :

Orang yang bodoh, tak tersangsikan lagi, selalu ia merasakan kepedihan hati, disebabkan pertermuannya dengan orang yang dibencinya dan oleh penceraiannya dengan orang yang dikasihinya; ah, karena nafsu angkara murkanya yang di timbulkan oleh kebodohannya.

Negara Indonesia memberikan kebebasan kepada masing-masing individu untuk memeluk Agama dan beribadah menurut kepercayaannya. Pemerintah menyadari adanya perbedaan di dalam menjalankan, melaksanakan dan menghayati ajaran agama, namun secara prinsip setiap umat mempunyai keyakinan atau kepercayaan terhadap Tuhan Yang Maha Esa (Suadnyana, 2020)

Menurut Hilda Taba dalam Mahmud Arif (Muhamad, 2008:18) menyatakan bahwa secara luas pendidikan adalah bagian dari "rekayasa sosial" yang secara sengaja dan sistematis berlangsung dalam sebuah kurun waktu tertentu sehingga ia tidak hanya berarti interaksi tatap muka (face to face) antara guru dan murid dalam lingkungan kelas. Peran pendidikan agama Hindu diharapkan mampu mengatasi dampak negatif yang dapat 
ditimbulkan dari kurangnya peran dan efektifitas pendidikan agama dengan menggunakan model dan strategi yang berbeda. Jika mempertimbangkan pendidikan agama Hindu yang dapat mengembangkan kecerdasan kognitif, emosional, dan psikomotorik, peserta didik tidak lepas dari Aspek-aspek seperti guru, siswa, kurikulum, lingkungan, dan model pembelajaran yang dipilih oleh guru. Aspek-aspek tersebut sangat berdampak pada hasil belajar yang diharapkan berupa efek pendidikan dan pendampingan (Jayanti, 2014). Pemahaman tersebut jika dikaji kembali ke awal, bahwasannya telah tertuang dalam Sarasamuscaya 304, sebagai berikut;

Matangnyan haywa ngwang tan jenek ring guna, prihantakitakin juga ya, hawya kawesa gumawayang dosa, apan ikang wwang durbuddhi dening tan pagunanya, makamusuh awaknya juga ya.

Terjemahannya :

Apapun alasannya janganlah membenci ilmu pengetahuan, tuntut dan kejarlah ilmu itu, pengetahuan akan membuka wawasan dan menjauhkan kita dari dosa-dosa; sebab orang yang bodoh tidak akan pernah sadar, bahwa yang terlebih dahulu harus diperangi dan ditundukkan adalah sisi pribadi yang bodoh dan jahat.

Berdasarkan isi sloka tersebut bahwasanya perlu memperluas wawasan meskipun terjadi perubahan yang sifatnya signifikan, agar menjadi pribadi yang lebih baik. Pendidikan dirancang untuk membentuk kepribadian siswa, dan dengan adanya perubahan pembelajaran di era baru ini, peningkatan kepribadian dapat dioptimalkan. Disiplin, kejujuran, ketekunan, keuletan, pantang menyerah, rasa ingin tahu, kemandirian dan kreativitas secara implisit diperkuat melalui pembelajaran online ini. Guru dan siswa tidak bertemu secara langsung (walaupun beberapa sekolah menggunakan media digital berupa video conference), namun siswa perlu memiliki keinginan yang tinggi dan kuat untuk belajar (Wiguna, 2021). Transformasi media pembelajaran di Prodi Penerangana agama Hindu dalam otimalisasi mata kuiah inti kelimuan, dilakukan dengan langkah-langkah sebagai berikut:

\section{Upaya-Upaya Dalam Mentransformasi Media Pembelajaran pada Program Studi Penerangan Agama Hindu}

Transformasi media pembelajaran memang harus selalu dikembangkan secara berkelanjutan oleh para pendidik dimanapun berada. Ada banyak pendapat yang menggolongkan jenis media, diantaranya dalam sebuah artikel yang ditulis(Mokhamad, 2018) menyebutkan bahwa menurut Seels dan Glasgow secara garis besar ada dua penggolongan media yang dinyatakan dengan "pilihan media tradisional" dan pilihan "media teknologi mutakhir". Pilihan media yang umum termasuk gambar diam yang diproyeksikan, gambar yang tidak diproyeksikan, audio, presentasi multimedia, gambar dinamis yang diproyeksikan, cetakan, permainan, dan kenyataan. Sedangkan pemilihan media teknologi terkini terdiri dari media berbasis telekomunikasi dan media berbasis mikroprosesor (Purba, 2020).

Penggunaan media teknologi informasi dan komunikasi kecenderungannya akan lebih familiar dikalangan mahasiswa karena sesuai dengan perkembangan jaman dan tentu mereka akan sangat menyukai pembelajaran yang dikemas menggunakan media teknologi informasi dan komunikasi. Penggunaan media yang sesuai dengan kondisi siswa sangat besar pengaruhnya terhadap keberhasilan pembelajaran dan menjadikan pembelajaran lebih bermakna. Adanya revolusi industri 4.0 juga berimbas kepada Revolusi Pendidikan 4.0 dimana revolusi ini menekankan penggunaan teknologi digital untuk memudahkan para tenaga pendidik atau peserta didik dalam melaksanakan kegiatan belajar mengajar, dengan adanya perubahan media pembelajaran ini akan mendukung terjadinya trasformasi digital pendidikan di Indonesia. Perubahan ini akan mendorong peserta didik untuk lebih melek teknologi. (Astini, 2020) 
Program Studi Penerangan Agama Hindu adalah salah satu program studi yang tergabung dalam Jurusan Dharma Duta, STAH Negeri Mpu Kuturan Singaraja. Sebagai sebuah lembaga pendidikan keagamaan yang baru berdiri, STAH Negeri Mpu Kuturan Singaraja selalu berupaya untuk mendorong stakeholdernya untuk mengembangkan diri baik dalam pendidikan ataupun pengembangan penguasaan media-media pembelajaran yang terupdate. Apalagi pada masa perkembangan teknologi 4.0 dan dunia menghadapi pandemi virus Covid-19 maka sangat dibutuhkan media pembelajaran yang mampu menjadi dasar pelaksanaan perkuliahan jarak jauh dengan memanfaatkan teknologi informasi untuk mengoptimalisasikan perkuliahan agar mendapatkan hasil yang optimal pada mata kuliah inti keilmuan pada Program Studi Penerangan Agama Hindu. Hasil yang diharapkan dari pemberian mata kuliah inti kepada mahasiswa adalah setelah selesai masa perkuliahan mahasiswa diharapkan memiliki keterampilan dan kecakapan dalam memberikan penyuluhan-penyuluhan kepada masyarakat baik secara langsung bertemu dengan masyarakat ataupun tampil di depan media baik audio maupun visual, dengan mengamalkan ajaran-ajaran agama Hindu, sesuai dengan kutipan dari Sarasamusccaya 308;

Paramarthanya, upacama ta pwa sang sadhu ngaranira, tumungkul dening kwehning gunanira, mwang wruhnira, kadyangganing pari, tumungkul dening bwatning wwahnya, mwang pangning kayu, tumungkul dening tobning phalanya.

Terjemahannya ;

Demikianlah disimpulkan, orang yang bajik, penuh pengetahuan, dan bijaksana, dapat dilihat dari kesabaran dan kerendahhatiannya; bagaikan keadaan padi yang merunduk lantaran berat buahnya, pun pohon yang dilebati buah merunduk lantaran menopang berat buah-buahnya

Upaya-upaya yang dilakukan oleh Program Studi Penerangan Agama Hindu STAH Negeri Mpu Kuturan Singaraja adalah:

\section{a. Menyiapkan Sarana Pendukung}

Program Studi Penerangan Agama Hindu berusaha selalu meningkatkan sarana perkuliahannya serta mendapatkan dukungan penuh dari lembaga STAH Negeri Mpu Kuturan Singaraja. Dukungan tersebut antara lain adalah:

\section{1) Lembaga Menyiapkan Laboratorium Siaran TV}

Perkembangan teknologi di era 4.0 menuntut seluruh kegiatan pendidikan dan pembelajaran beradaptasi dengan kemajuan teknologi. Dengan adanya perkembangan ini, perguruan tinggi dituntut untuk lebih memanfaatkan teknologi informasi dan media digital. Mpu Kuturan TV merupakan salah satu fasilitas yang dapat digunakan sebagai wadah promosi kampus dan kreativitas mahasiswa. Transformasi digital di perguruan tinggi tidak hanya membangun infrastruktur digital, tetapi juga membangun fasilitas dan mengubah pola pikir untuk memenuhi kebutuhan mahasiswa dan civitas akademika lainnya yang terus berkembang dalam membangun lingkungan pembelajaran berjejaring.

\section{2) Peningkatan Kapasitas Bandwidth Internet}

Dewasa ini, penggunaan internet sudah tidak asing lagi di masyarakat, apalagi bagi pendidik dan peserta didik. Bandwidth adalah kapasitas maksimum jalur komunikasi yang bekerja pada kecepatan bit per detik saat mengirim data dari server ke klien. Pada lembaga STAH Negeri Mpu Kuturan Singaraja untuk memaksimalkan dan juga memperlancar proses penggunaan internet untuk mendukung segala aktivitas baik perkuliahan maupun pekerjaan yang berbasis internet maka, pada tahun 2019 kecepatan bandwidth di tingkatkan dari 30 Mbps menjadi 40 Mbps, pada tahun 2020 kembali ditingkatkan karena $100 \%$ kegiatan perkuliahan dilaksanakan secara daring yang mengharuskan kecepatan internet jauh lebih besar dan didukung dengan penambahan akses poin yang disebar diseluruh areal kampus agar internet menjangkau seluruh wilayah kampus. 


\section{b. Mengikuti Pelatihan-Pelatihan, Baik Secara Luring ataupun Daring Mengenai Penggunaan Media dalam Proses Pembelajaran.}

Lembaga tidak dapat sepenuhnya mengandalkan program pemberdayaan instruktur yang dimiliki atau diprogramkan oleh pemerintah, tetapi juga dapat dilaksanakan secara mandiri, yaitu dengan mengikuti kursus pelatihan lanjutan, webinar dan lain-lain secara luring ataupun daring. Apalagi saat ini, karena pengaruh pandemi Covid-19 yang mengharuskan semua untuk tetap berada di rumah melaksanakan kegiatan kerja di rumah sampai kegiatan belajarpun dilaksanakan dari rumah, banyak kursus pelatihan online yang bisa diikuti oleh para dosen ini.

Dosen pada Program Studi Penerangan Agama Hindu dianjurkan untuk mengikuti pelatihan dan webinar online ini dikarenakan beberapa hal yaitu:

1) Terbatasnya ruang gerak dan pembatasan yang berlaku dimasyarakat karena adanya pandemi Covid-19, makaworkshop, pelatihan ataupun seminar bersifat luring, namun banyak sekali webinar-webinar yang diselenggarakan oleh lembaga-lembaga pendidikan yang bersifat nasional, jika ini diikuti maka akan berefek sangat positif bagi perkembangan pengetahuan para dosen di Program Studi Penerangan Agama Hindu.

2) Webinar dapat diikuti dari mana saja, di mana saja dan kapan saja asalkan ada jaringan internet serta bisa diikuti secara gratis.

3) webinar ataupun pelatihan yang bersifat online juga bisa direkam video sepanjang pelaksanaan kegiatan, maka kita bisa memutarnya kembali dan melihat bagian mana yang belum dipahami

\section{c. Bertukar Informasi dan Ilmu dalam Pengembangan Media Pembelajaran.}

Pertukaran informasi ini bisa dilaksanakan pada saat rapat, Forum Group Discussion ataupun ketika kumpul bersama, para dosen di Prodi Penerangan Agama Hindu saling bertukar informasi dan mengimbaskan apa yang didapatkan dari media internet, pelatihan, webinar, wokshop yang diikuti terutama dalam pengembangan media pembelajaran untuk mendukung pelaksanaan perkuliahan. Hal ini dilakukan karena tidak semua dosen bisa mengikuti acara-acara seperti webinar ataupun pelatihan, dikarenakan terbentur dengan jadwal mengajar, mengikuti kegiatan-kegiatan yang ditugaskan baik dari lembaga maupun yang ditugaskan oleh pimpinan langsung.

\section{d. Penugasan-Penugasan Berbasis Media Sosial}

Secara umum, sistem pembelajaran online yang menggunakan metode penugasan mirip dengan pembelajaran offline. Namun, metode penugasan di sini adalah untuk membantu siswa belajar secara fleksibel dan kreatif dalam mengintegrasikan materi yang ditugaskan dengan penggunaan teknologi seperti smartphone, komputer dan laptop untuk membantu dalam membuat tugas kuliah. Melalui metode ini peserta didik dapat melakukan dua hal sekaligus. Salah satunya adalah dapat memahami materi dan memiliki keberanian untuk menyajikan materi melalui video, podcast, dan voicenote. Selain itu, peserta didik dapat melatih keterampilan mereka dalam menggunakan aplikasi perekaman dan pengeditan video. Media sosial yang sering menjadi tempat untuk mengupload video dari mahasiswa adalah: Facebook, YouTube, dan Instagram. Media-media ini paling banyak digemari dan digunakan oleh kaum milenial seperti mahasiswa, dosen maupun masyarakat umun. Sehingga tepat kiranya menjadi tempat untuk membagikan tugas yang dibuat mahasiswa.

\section{Transformasi Media Pembelajaran Yang Dilaksanakan Pada Program Studi Penerangan Agama Hindu}

Pendidikan merupakan salah satu aspek yang dijadikan sebagai wadah dalam pembentukan karakter anak (Ulyan, 2018:5). Dengan menjadikan pendidikan sebagai upaya dan kegiatan yang penuh proses humanisasi, hal tersebut sesungguhnya telah mampu menjadikan pendidikan sebagai sebuah proses perubahan sosial menuju ke arah kemajuan. 
Proses pendidikan ini dicirikan dengan teologi pembebasan dari teologi tradisional, dialog lengkap dari proses non-dialog, kehidupan sosial yang terbuka dari kehidupan masyarakat yang tertutup, dan transisi situasi ke masyarakat yang jauh dari pengetahuan menuju masyarakat yang sadar akan pengetahuan. Oleh karena itu, pendidikan merupakan sarana penyadaran untuk membawa manusia kembali ke fitrah manusia. Selain itu, pendidikan merupakan kunci sukses dalam menghadapi globalisasi. Oleh karena itu, dalam proses pendidikan, kondisi yang akan terus berubah menuntut pendidik harus mampu menguasai berbagai media pembelajaran. Media merupakan salah satu penunjang dalam proses pembelajaran. Berhasil atau tidaknya proses pembelajaran sangat tergantung pada media yang digunakan. Media dapat digunakan untuk menyampaikan pesan dari pengirim kepada penerima untuk merangsang pikiran, perasaan, pesan, dan minat selama proses pembelajaran berlangsung (Arsyad, 2005).

Dosen pengajar pada program studi Penerangan Agama Hindu mengoptimalkan kegiatan belajar mengajar dengan memanfaatkan teknologi dan media pembelajaran yang terupdate, diantaranya aplikasi-aplikasi penunjang kegiatan pembelajaran, penggunaan media ajar, serta memaksimalkan fungsi internet, sehingga memudahkan peserta didik dalam mengikuti perkuliahan. Pada prinsipnya, teknologi ini memberikan keleluasaan bagi pengajar dan peserta didik dalam menerapkan pembelajaran jarak jauh. Berbagai jenis platform disediakan untuk memfasilitasi pembelajaran jarak jauh dan untuk membantu pengajarn dalam mengevaluasi peserta didik tanpa kontak tatap muka. Platform seperti, Instagram, Facebook, Canva, Google Classroom, Youtube, Whatsapp, Zoho Forms, Zoom, Google Meet, Canva, Google Classroom, Youtube, Whatsapp, Zoho Forms, Zoom, Google Meet, Mpu Kuturan TV, dan E-Book bahan ajaryang diberikan pada peserta didik bisa dipadupadankan untuk menghasilkan media dan proses pembelajaran yang lebih efektif.

Pembelajaran online yang sukses tidak hanya bergantung pada peran teknologi internet, tetapi juga pada kualitas sumber daya manusia. Teknologi internet tidak berdampak signifikan jika operator atau personel pengguna tidak memiliki pengetahuan dan keterampilan yang memadai untuk menggunakan dan mengelola teknologi tersebut. Oleh karena itu, memahami teknologi merupakan faktor kunci dalam keberhasilan pembelajaran online. Sehingga dosen-dosen pada program studi Penerangan Agama Hindu diharuskan untuk mengikuti pelatihan-pelatihan, baik secara luring ataupun daring mengenai penggunaan media dalam proses pembelajaran.

\section{a. Pemilihan Media Pembelajaran Yang Dilaksanakan Pada Program Studi Penerangan Agama Hindu}

Multimedia adalah media yang meiliki beberapa jenis media dan perangkat yang tertanam dalam suatu proses atau kegiatan pembelajaran. Media pembelajaran, bila digunakan oleh sejumlah individu, kelompok, atau khalayak, memiliki tiga fungsi utama: (a) minat dan motivasi perilaku, (b) penyajian informasi, dan (c) instruksi. Kemp dan Dayton (Arsyad, 2005). Dalam pemilihan media yang hendak digunakan tidak boleh sembarangan dan harus dipilih menurut kriteria tertentu. Kesalahan baik dalam pemilihan jenis media maupun pemilihan topik akan berdampak panjang yang tidak diinginkan di kemudian hari. Secara umum, dosen pengajar di Prodi Penerangan Agama Hindu memiliki kriteria yang harus diperhatikan dalam memilih media pembelajaran, yaitu:

1) Kesesuaian tujuan dengan Kurikulum, Silabus, RPS, dan kontrak perkuliahan, dalam pembelajaran terdapat tujuan yang harus dicapai mencakup ranah kognitif, efektif, dan psikomotor

2) Sasaran didik, setiap kelas memiliki karakteristik yang berbeda dalam kegiatan belajar mengajar, sehingga dosen harus fleksibel dalam memilih media pembelajaran berdasarkan kesepakatan dengan siswa, seperti motivasi dan minat belajar yang ada. Oleh karena itu, media harus memenuhi persyaratan tersebut. 
3) Karakteristik media pembelajaran, setiap media pembelajaran yang menjadi ciri media pembelajaran memiliki kelebihan dan kekurangannya masing-masing, dosen pengajar di prodi Penerangan Agama Hindu perlu memadukan media pembelajaran dengan baik sesuai dengan tujuan pembelajaran yang dicapai.

4) Waktu, di sini berarti waktu yang diperlukan untuk mengadakan media pembelajaran atau membuat media pembelajaran yang dipilih, dan waktu yang tersedia atau yang kita miliki dalam pembelajaran.

5) Biaya, dosen pengajar di prodi Penerangan Agama Hindu mempertimbangkan faktor biaya dalam memilih media pembelajaran. Bukankah penggunaan media pada dasarnya bertujuan untuk meningkatkan efisiensi dan efektivitas pembelajaran. Apa artinya menggunakan media ketika hasilnya tidak berguna.

6) Ketersediaan, STAHN Mpu Kuturan Singaraja telah menyiapkan Mpu Kuturan TV di sebagai media pembelajaran iklan kampus dan sebagai wadah kreativitas mahasiswa dalam transformasi digital pembelajaran.

7) Konteks penggunaan media pembelajaran, penggunaan menggambarkan kondisi dan strategi penggunaan media. Dalam hal ini dosen pengajar di prodi penerangan akan menyesuaikan penggunaan media pembelajaran untuk keberhasilan pembelajaran.

Kriteria digunakan utamanya untuk dalam memilih media yang siap digunakan untuk media pembelajaran. Dalam proses belajar mengajar secara daring di prodi Penerangan Agama Hindu, dosen pengajar menggunakan aplikasi-aplikasi Canva, Google Classroom, Youtube, Whatsapp, Zoho Forms, Zoom, Google Meet, Canva, Google Classroom, Youtube, Whatsapp, Zoho Forms, Zoom, Google Meet, Mpu Kuturan TV, dan membuat e-book bahan ajar

\section{b. Pelaksanaan Transformasi Media Pembelajaran Jarak Jauh di Prodi Penerangan Agama Hindu}

Pembelajaran jarak jauh adalah proses pembelajaran di mana peserta didik dan pendidik tidak bertemu langsung di satu tempat. Kementerian Pendidikan dan Kebudayaan menyatakan dalam Surat Edaran Nomor 4 Tahun 2020 bahwa pembelajaran jarak jauh ada dua jenis: Pembelajaran offline (di luar jaringan) dan online (dalam jaringan). Pembelajaran offline adalah pembelajaran yang tidak menggunakan jaringan internet atau intranet. Sistem pembelajaran offline (di luar jaringan) berarti pembelajaran yang berlangsung menggunakan media LCD, presentasi power point, laboratorium, dan lainnya.

Pembelajaran online adalah pembelajaran yang ditujukan untuk menjangkau kelompok yang besar dan luas dengan menggunakan jaringan internet (Yanti, 2020). Proses Setelah melakukan observasi dan wawancara kepada para dosen, pembelajaran daring di Prodi Penerangan Agama Hindu memanfaatkan kemajuan teknologi seperti teknologi multimedia, yaitu aplikasi-aplikasi Canva, Google Classroom, Youtube, Whatsapp, Zoho Forms, Zoom, Google Meet, Canva, Google Classroom, Youtube, Whatsapp, Zoho Forms, Zoom, Google Meet, Mpu Kuturan TV, dan membuat e-book bahan ajar. Pembelajaran online dapat dilakukan secara besar-besaran tanpa batasan jumlah peserta dan dapat dilakukan secara gratis atau dipungut biaya (Qomarudin, 2015).

Proses pembelajaran online yang digunakan pada di prodi Penerangan Agama Hindu dilakukan dalam dua model yaitu satu arah dan dua arah. Di sini, pembelajaran online satu sarah dilakukan ketika dosen memberikan tugas dan materi melalui media online, dan peserta didk secara aktif dan mandiri mempelajari materi dan menyelesaikan tugas yang diberikan. Pembelajaran online dua arah, di sisi lain, terjadi ketika dosen dan peserta didik berada dalam ruang virtual yang sengaja dimaksudkan untuk proses dialog antara dosen dan peserta didik. Proses interaksi ini dapat dilakukan dalam bentuk pembagian materi yang menggambarkan tugas-tugas yang dapat diikuti secara langsung peserta didik. Salah satu keberhasilan proses pembelajaran online satu arah dan dua arah ditentukan oleh pemanfaatan teknologi yang 
menyediakan layanan dialog antara dosen dan mahasiswa. Sarana untuk mendukung interaksi tersebut dalam pembelajaran online disediakan oleh banyak platform digital dengan kemampuan yang berbeda tergantung pada tujuan interaksi yang dicapai.

\section{Implikasi Transformasi Media Pembelajaran Dalam Upaya Optimalisasi Perkuliahan Mata Kuliah Inti Keilmuan Prodi Penerangan Agama Hindu.}

Transformasi media pembelajaran dalam dunia pendidikan sangat penting untuk mengikuti dinamika perkembangan zaman. Kegiatan pembelajaran tidak lagi hanya sebatas di ruang kelas. Di era digital ini pembelajaran bisa dilakukan dimanapun dan kapanpun secara virtual yang bisa menembus ruang dan waktu. Media dan sumber pembelajaranpun dewasa ini juga sangat beragam. Dosen dan mahasiswa dapat mengakses sumber belajar yang bervariasi dari berbagai sumber. Kegiatan pembelajaran di era digital membutuhkan media pembelajaran berbasis teknologi informasi untuk mengakomodasi tuntutan kurikulum merdeka belajar. Para pendidik di Prodi Penerangan Agama Hindu dalam proses pembelajaran menggunakan berbagai macam media pembelajaran baik yang konvensional hingga memanfaatkan teknologi digital. Dengan demikian menggunakan media pembelajaran berbasis teknologi digital menjadi suatu keniscayaan. Penggunaan media pembelajaran berbasis digital ini banyak memberikan implikasi positif baik bagi dosen, mahasiswa maupun lembaga, yaitu:

\section{a. Meningkatkan Literasi Digital}

Menurut buku Digital Literacy Paul Gilster, literasi digital didefinisikan sebagai kemampuan untuk memahami dan menggunakan berbagai bentuk informasi dari berbagai sumber yang diakses melalui perangkat komputasi (Gilster, 1997). (Bawden, 2001)menawarkan pemahaman baru tentang kemampuan digital yang berakar pada komputer dan literasi informasi. Dalam pandangan Bawden, kemampuan digital kemungkinan terkait dengan keterampilan teknis dalam mengakses, mengedit, memahami, dan menyebarkan informasi. Prodi Penerangan Agama Hindu STAH Negeri Mpu Kuturan Singaraja dalam melaksanakan proses pembelajaran mata kuliah inti keilmuan memanfaatkan berbagai media guna mengoptimalkan proses pembelajaran. Hal ini terlihat dari kuisioner yang disebarkan kepada mahasiswa Prodi Penerangan Agama Hindu dalam format google form.

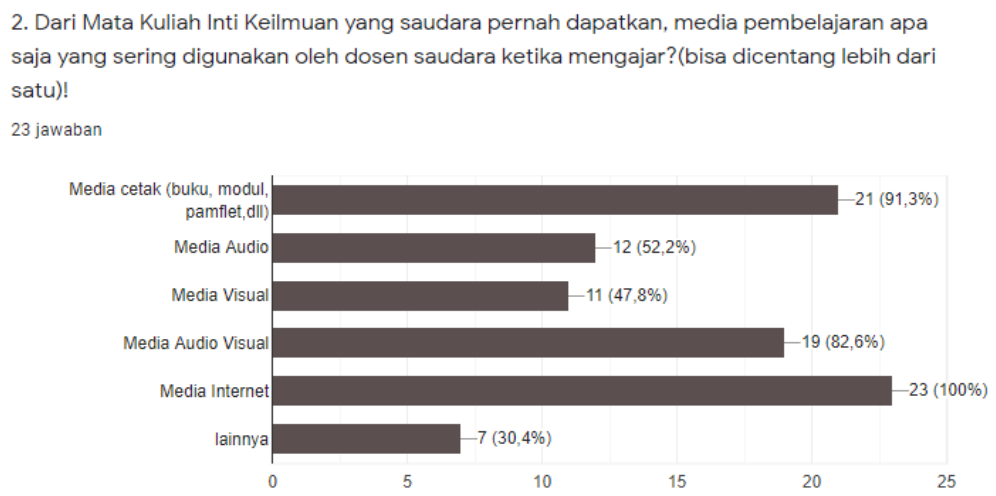

Grafik 1. Pemanfaatan Media

Dari hasil survei kuisioner tersebut dapat dilihat bahwa penggunaan media pembelajaran dalam bentuk media internet menempati persentase yang paling besar yakni $100 \%$. Hal ini menandakan bahwa pembelajaran dalam bentuk media digital atau internet menjadi sebuah inovasi dalam usaha mengoptimalkan pembelajaran pada Prodi Penerangan Agama Hindu STAH Negeri Mpu Kuturan Singaraja serta menjadi salah satu pilihan dalam melakukan proses belajar pada masa pandemi Covid-19. 


\section{b. Kemudahan dalam Mengakses}

Pembelajaran online dengan menggunakan berbagai media digital telah memberikan akses terbesar untuk kegiatan pembelajaran inovatif di dunia pendidikan, menciptakan lingkungan belajar yang lebih beragam dan tidak membosankan. Berbagai aplikasi pembelajaran yang mudah diakses dan sering digunakan oleh dosen dan mahasiswa pada Prodi Penerangan Agama Hindu STAH Negeri Mpu Kuturan Singaraja adalah aplikasi Whatsapp, Google Classroom, Google Meet, Zoom Meeting, dan lain-lain. Fitur yang disajikan oleh aplikasi belajar tersebut sangat mudah diakses, serta baik dosen maupun mahasiswa dapat dengan mudah mengikuti berbagai bentuk kegiatan belajar, seperti kegiatan seminar yang kini bertransformasi menjadi webinar guna meningkatkan ilmu dan pengetahuannya.

\section{c. Bersifat Fleksibel}

Di era yang serba digital ini, pembelajaran secara daring menawarkan fleksibilitas baik kepada para pendidik maupun peserta didiknya. Mereka bisa melakukan banyak kegiatan dalam waktu yang bersamaan. Para peserta didik mempunyai keleluasaan dalam mengatur kecepatan belajarnya, menentukan waktu pengumpulan tugas, bahkan mengatur jadwal kuliah. Selain itu, dengan adanya pembelajaran secara daring juga memberikan kesempatan kepada mereka yang ingin kuliah sambil bekerja untuk membantu perekonomian keluarga atau bekerja sekedar untuk menambah uang jajan. Pembelajaran daring juga membuka kesempatan bagi para pekerja kantoran yang ingin belajar lagi demi meningkatkan kemampuan mereka dengan kembali berkuliah. Hal ini dikarenakan perkuliahan bisa dilaksanakan secara daring dan mengambil waktu di luar jam kantor.

\section{d. Hemat dan Berkualitas}

Hemat dalam pembelajaran daring menyangkut hemat biaya dan waktu. Pelaksanaan pembelajaran secara daring sangat menghemat masalah keuangan. Pembelajaran bisa dilaksanakan dimanapun dan kapanpun, dengan demikian biaya kost bagi para perantau dan biaya transportasi bagi yang rumahnya jauh bisa diatasi. Disisi lain, pembelajaran secara daring juga hemat akan waktu, sehingga waktu yang berlebih ini bisa dimanfaatkan untuk melakukan kegiatan lain yang lebih bermanfaat. Selain hemat biaya dan waktu, kepopuleran pembelajaran daring bisa meningkatkan kualitas pembelajaran. Hal ini dikarenakan para peserta didik memungkinkan untuk diajar oleh pengajar terbaik dan pengajar tamu professional dari kampus lain secara virtual melalui akses yang mudah.

\section{e. Terasahnya kemampuan Dosen dan Mahasiswa tampil di depan Media}

Kehadiran Mpu Kuturan TV memberikan dampak yang begitu besar bagi segenap civitas akademika STAH Negeri Mpu Kuturan Singaraja. Melalui media ini mahasiswa dan dosen dapat mengembangkan hardskill dan softskillnya dalam dunia pendidikan. Mpu Kuturan TV memberikan kesempatan bagi dosen dan mahasiswa pada Prodi Penerangan Agama Hindu untuk tampil di depan kamera, bisa dalam bentuk talkshow, pemberian Dharma Wacana, maupun Dharma Gita. Dosen pada prodi Penerangan Agama Hindu sering diundang untuk mengisi talkshow/ podcast sebagai narasumber di Mpu Kuturan TV.

\section{f. Mahasiswa Mampu Memanfaatkan Media Sosial Sebagai Tempat Untuk Pengembangan Diri}

Prodi Penerangan Agama Hindu mempunyai akun media sosial yang dikelola oleh mahasiswa dan dosen untuk bersosialisasi di dunia maya. Mahasiswa aktif dalam menggunakan media sosial seperti Facebook, YouTube dan Instagram untuk memposting kegiatan Tri Dharma Perguruan Tinggi yakni pendidikan dan pengajaran, penelitian, dan pengabdian kepada masyarakat yang dilaksanakan oleh para dosen dan mahasiswa. Selain itu mahasiswa juga aktif memposting kegiatan yang dilakukan di Himpunan Mahasiswa Program Studi (HMPS) Prodi Penerangan Agama Hindu. 


\section{g. Meningkatnya Kemampuan Dosen dan Mahasiswa dalam Penggunaan IT}

Saat ini, transformasi digital bukan lagi pilihan melainkan menjadi sebuah keharusan. Dunia sudah mendigital, tidak ada lagi celah untuk menolaknya. Guna meningkatkan penguasaan IT, dosen-dosen di Prodi Penerangan Agama Hindu sudah banyak yang memanfaatkan YouTube sebagai media pembelajaran dengan pemberian tugas kepada mahasiswa berupa video dan mahasiswa menguploadnya di channel YouTube mereka(Kamhar, 2019). Konten yang dibuat oleh mahasiswa bisa langsung diunggah oleh masing-masing mahasiswa sehingga mahasiswa yang lain bahkan orang lain dapat melihat konten yang mereka unggah. Beberapa dosen yang pernah memberikan tugas berupa video dan di unggah di channel YouTube antara lain I Kadek Abdhi Yasa, M.Pd. pada mata kuliah Dharma Wacana dan Seni Sakral, serta I Gede Sutana, S.Kes.H., M.Si. pada mata kuliah Antropologi.

\section{h. Meningkatnya Nilai Mahasiswa}

Transformasi media pembelajaran dalam upaya optimalisasi perkuliahan mata kuliah inti keilmuan Prodi Penerangan Agama Hindu berimplikasi pada meningkatnya nilai mahasiswa. Hal ini disebabkan ketertarikan mahasiswa belajar menggunakan media pembelajaran yang beragam dari dosen seperti Canva, Google Classroom, YouTube, WhatsApp, Zoho Forms, Zoom, Google Meet dan E-book. (Alami, 2020). Menurut informan Kadek Ria Parwati (wawancara, 29 April 2021) mahasiswa yang kini semester IV mengatakan bahwa: "Berbagai media pembelajaran yang digunakan dosen selama proses pembelajaran menarik dan mempengaruhi semangat belajar siswa. Dengan semangat belajar yang tinggi dan atmosfer belajar yang bagus mahasiswa mengikuti perkuliahan dengan serius menyebabkan adanya peningkatan nilai baik tugas-tugas maupun nilai ujian”.

\section{i. Kesiapan Lembaga STAHN Mpu Kuturan Singaraja Pada Transformasi Digital}

Saat ini, transformasi digital sangat dibutuhkan dan diperlukan agar civitas akademika di kampus tetap relevan dengan perkembangan yang terjadi. Transformasi digital di perguruan tinggi bertumpu pada proses dan strategi dalam penggunaan teknologi digital untuk secara cepat mengubah cara lembaga pendidikan bekerja dan melayani mahasiswa, dosen, pegawai, industri, orang tua dan pemerintah meningkat. Kampus STAHN Mpu Kuturan Singaraja sudah siap dengan tantangan transformasi digital tersebut. Hal ini dibuktikan dengan sudah dipenuhinya beberapa persyaratan di atas seperti civitas kampus dibekali keterampilan digital, penerimaan mahasiswa baru online, platform pembelajaran jarak jauh, SIAK, presensi digital, webinar kampus dan work from home. Selain hal tersebut berkaitan dengan pandemi Covid-19 dalam bidang proses pembelajaran atau kegiatan yang bersifat pertemuan yang dilaksanakan secara daring, lembaga Kampus STAHN Mpu Kuturan Singaraja juga sudah memfasilitasi tenaga pendidik beberapa aplikasi pembelajaran salah satunya yakni aplikasi zoom meeting

\section{Kesimpulan}

Proses pengoptimalisasi proses perkulihan pada mata kuliah Agama Hindu pada keilmuan Prodi Penerangan Agama Hindu STAH Negeri Mpu Kuturan Singaraja, para dosen di lingkup prodi melakukan upaya-upaya dalam bentuk transformasi media pembelajaran. Upaya-upaya tersebut yaitu: a) Menyiapkan sarana pendukung (laboratorium siaran berupa Mpu Kuturan TV) b) Mengikuti pelatihan-pelatihan (luring dan daring); c) Saling bertukar informasi dan ilmu dalam pengembangan media-media baru; d) Penggunaan aplikasi-aplikasi yang tidak berbayar sebagai media melakukan perkuliahan; e) Membuat E-Book bahan ajar. Penunjang langkah-langkah tersebut dalam proses transformasi media pembelajaran yang dilaksanakan pada Program Studi Penerangan Agama Hindu mencakup: a) tahap persiapan, b) tahap pelaksanaan/penyajian, c) tahap tindak lanjut. Langkah mengoptimalkan proses perkuliahan mata kuliah inti keilmuan pada Prodi Penerangan Agama Hindu melalui 
transformasi media pembelajaran, adapun implikasi yang diperoleh, yaitu: a) Meningkatkan Literasi Digital; b) Memperoleh kemudahan dalam mengakses informasi; c) Bersifat fleksibel; d) Hemat dan berkualitas; e) Dosen dan mahasiswa bisa tampil di depan kamera (Mpu Kuturan TV); f) Mahasiswa terampil menggunakan media social; g) Meningkatnya Kemampuan Dosen dan Mahasiswa dalam Penggunaan IT; h) Meningkatnya Nilai Mahasiswa; dan i) Lembaga STAH Negeri Mpu Kuturan Singaraja siap dalam hal transformasi digital demi kemajuan bersama.

\section{Daftar Pustaka}

Alami, Y. (2020). Media Pembelajaran Daring Pada Massa Covid-19. Tarbiyatu wa Ta'lim: Jurnal Pendidikan Agama Islam, Vol. 2 Nomor 1, , 49-56.

Arsyad, A. (2005). Media Pembelajaran. Jakarta: Raja Grafindo Persada.

Astini, N. (2020). Tangtangan Dan Peluang Pemanfaatan Teknologi Imformasi Dalam Pembelajaran Online Masa Covid-19. Cetta: Jurnal Pendidikan, Vol. 3 Nomor 2, 241255.

Anwar dan Riadi. (2017). Analisis Investigasi Forensik WhatsApp Messenger Smartphone Terhadap Wahtsapp Berbasis Web. Jurnal Ilmu Teknik elektro Kompuer Dan Informatika, 3(1), 2-10.

Arikunto, S. (2010). Metode Penelitian Kualitatif. Bandung : Rhineka Cipta.

Bawden, D. (2001). Information and digital literacies: a review of concepts. Journal of documentation.

Bilfaqih, Y., \& Qomarudin, M. N. (2015). Esensi Pengembangan Pembelajaran Daring. Yogyakarta: Deepublish.

Bungin, B. (2010). Metodologi Penelitian Kuantitatif. Jakarta. Kencana Prenada Media Group.

Dewi, E. (2012). Transformasi Sosial dan Nilai Agama. Substantia: Jurnal Ilmu-Ilmu Ushuluddin, 14(1), 112-121.

Diantara, I. G. (2011). Novel Ngabih Kasih Ring Pesisi Lebih (Analisis Struktur dan Nilai). Skripsi (tidak diterbitkan). Denpasar: Fakultas Dharma Acarya, IHDN Denpasar.

Dryden, G. \& Vos. J. (2001). Revolusi Cara Belajar. Bandung: Kaifa

Falahudin, I. (2014). Pemanfaatan media dalam pembelajaran. Jurnal Lingkar Widyaiswara, 1(4), 104-117.

Gilster, P. (1997). Digital Literacy. John Wiley \& Sons. New York.

Guba, D. (2001). Teori dan Paradigma Penelitian sosial. Yogyakarta: PT. Tiara Wacana.

Jayanti, A. I. (2014). Pola Pendidikan Agama Hindu Dalam Upanisad Dikaitkan Dengan Pendidikan Modern Di Kelas III N 7 Gianyar. UNHI Denpasar: (Skripsi Tidak Diterbitkan).

Kamhar, M. L. (2019). Pemanfaatan Sosial Media Youtube Sebagai Media Pembelajaran Bahasa Indonesia Di Perguruan Tinggi. Intelegensi: Jurnal Ilmu Pendidikan Vol. 1 Nomor 2, , 1.

Karim, B. (2020). Pendidikan Perguruan Tinggi Era 4.0 Dalam Pandemi Covid-19 (repleksi Sosiologis). Education and Learning Journal, Vol. 1 Nomor 2, 102-112.

Muhammad, A. (2014). Analisis Optimalisasi Pelayanan Konsumen Berdasarkan Teori Antrian Pada kaltimgps.com Di Samarinda. Jurnal: Ilmu Administrasi Bisnis, 2(3).

Nasional, D. P. (2003). Standar Kompetensi Mata Pelajaran Pendidikan Agama Hindu. https://123dok.com/document/q7o52noy-kurikulum-standar-kompetensi-matapelajaran.html.

Purba, R. A. (2020). Teknologi Pendidikan. Medan: Yayasan Kita Menulis. 
Qomarudin, Y. B. (2015). Esensi Pengembangan Pembelajaran Daring (Panduan Berstandar Pengembangan Pembelajaran Daring untuk Pendidikan dan Pelatihan). Yogyakarta: CV. Budi Utama.

Suadnyana, I. B. P. E., \& Darmawan, I. P. A. (2020). Nilai Pendidikan Agama Hindu Dalam Lontar Siwa Sasana. Cetta: Jurnal Ilmu Pendidikan, 3(2), 371-391.

Suryono, A. (2019). Teori dan Strategi Perubahan Sosial. Jakarta: Buni Aksara.

Wiguna, I. M. A. (2021). Idealisme Ekalawya Dalam Wiracarita Mahabharata Dan Refleksi Pendidikan Di Era Tatanan Baru. Jurnal Penelitian Agama Hindu, 5(3), 144-157.

Yanti, M. T., Kuntarto, E., \& Kurniawan, A. R. (2020). Pemanfaatan Portal Rumah Belajar Kemendikbud Sebagai Model Pembelajaran Daring di Sekolah Dasar. Adi Widya: Jurnal Pendidikan Dasar, 5(1), 61-68.

Zaini, H., \& Dewi, K. (2017). Pentingnya media pembelajaran untuk anak usia dini. Raudhatul Athfal: Jurnal Pendidikan Islam Anak Usia Dini, 1(1), 81-96. 